\title{
The short-run performance of equity issues in South Africa: Bad timing or a last resort?
}

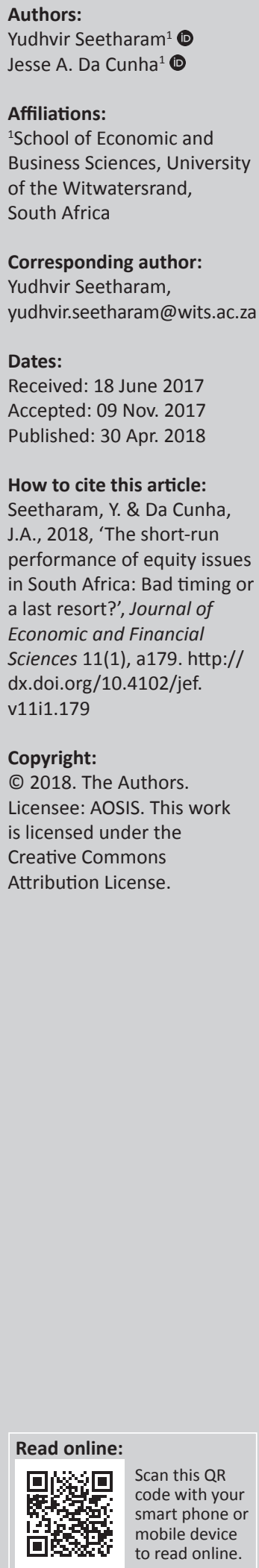

Understanding the stock market's reaction to secondary equity offerings (SEOs) is vital for managers who are commonly tasked with deciding on how to finance their firm's operations. This study investigated the short-run performance of firms conducting equity issuance on the Johannesburg Stock Exchange (JSE) over the period 1998-2015 by exploring both rational and behavioural models in predicting SEO behaviour. Event-study analysis reveals that the market generally reacts negatively to the announcement of SEOs with a statistically significant average two-day cumulative abnormal return of $-2.6 \%$. We also found that the probability of a firm conducting a SEO is significantly negatively related to the number of years listed and the future share return. Although it would make sense that more corporate activity takes place during periods of high investor sentiment, there is no significant evidence that firms conducting SEOs are attempting to time the market.

\section{Introduction}

Literature has documented that the stock market's reaction to a firm's announcement of a secondary equity offering (SEO) is generally negative (Ritter 2003; Smith 1986). These findings are consistent with the adverse selection model proposed by Myers and Majluf (1984). The adverse selection model, which is widely regarded amongst the existing literature as the conventional explanation for these negative announcement effects, proposes that investors view the decision of a firm to issue shares as 'bad news' about the true value of that firm. This is because of the incentives that managers have to issue shares when they are overvalued in order to benefit existing shareholders, at the expense of new shareholders.

Issuing new shares, despite its commonality and enormous importance, has presented a challenge to the academic institution. Despite the existing literature delving into the nuances of the equity issuing process, there remains an air of uncertainty and inconsistency regarding the consequences of issuing new shares. Although clear patterns have emerged to help forge a better understanding of the performance of firms surrounding SEOs, explaining these patterns has been a source of great debate.

Despite the importance of understanding the market's reaction to a critical component of a firm's financing activity, the empirical research surrounding the long-run performance of firms conducting SEOs has largely been overlooked in the South African context, with the existing South African literature focusing purely on capital structure decisions or initial public offerings (IPOs).

The most prominent explanation for SEO underperformance, which emerges from behavioural finance, is the market timing theory. This theory assumes that managers attempt to time the market by issuing shares when they are overvalued (Baker \& Wurgler 2002) and is based on the precept that managers are able to distinguish between whether their firm's shares are overvalued or undervalued. Therefore, in order to test the predictions and implications of the market timing theory, a method of testing for the mispricing of shares is required. Based on the existing literature, it appears that the market-to-book ratio, the pre-issue abnormal returns and the post-issue abnormal returns are amongst the most prevalent gauges of share mispricing, which can serve to highlight a window of opportunity for managers wishing to time the market. However, these measures have a major flaw in that they might not necessarily indicate mispricing (DeAngelo, DeAngelo \& Stulz 2010).

In response to the above-mentioned criticisms, the investor sentiment index developed by Baker and Wurgler (2006) has emerged as a popular tool used to test many behavioural theories. Periods of high sentiment as indicated by the index are often used as a more reliable indication 
of a window of opportunity for managers to time the market. An additional benefit of using this index is that it uses a combination of various measures used to proxy investor sentiment and also has the flexibility to adapt to different stock exchanges. Our study adopts a new approach to testing these behavioural market timing theories by the use of the investor sentiment index. We use the investor sentiment index created by Dalika and Seetharam (2015) which they adapted for South Africa. Ceteris paribus, shares are more likely to experience deviations from fundamentals during periods of high investor sentiment (Chou \& Lin 2015). Therefore, if managers are attempting to time the market in order to issue overvalued shares, investor sentiment should play a significant role in a firm's decision to issue equity.

On the contrary, rational explanations for SEO underperformance centre on the concept of the mispricing of risk. Put simply, these hypotheses attempt to explain the underperformance of SEOs as a failure of the model specification in capturing risk, hence the failure of the said model in explaining returns. The argument here is that the lower returns earned by SEO firms are in response to the lower risk faced by holding the shares of these firms. The difficulty in this argument is that it avoids the burden of proof.

This study comprehensively tests the short-run effects of SEOs in the context of the Johannesburg Stock Exchange (JSE) by focusing on the relevant behavioural and rational explanatory models proposed in previous literature. We use the terms 'SEOs' and 'rights issues' interchangeably because in the South African context firms conduct rights issues and not SEOs. In a rights issue, there are no new investors, so a priori, we expect there to be no market timing. However, according to the pecking order theory of Myers and Majluf (1984), the need for external financing may be the reason for a rights issue (along with its associated reasons). The first part of this study tests the announcement effects associated with SEOs, whereas the secondary focus is to analyse the influence of investor sentiment on the decision to conduct SEOs and the market's reaction to the SEO. These objectives refer to the behavioural explanations of SEO performance with a particular focus on the market timing theory. Finally, the study aims to investigate the influence of the explanatory variables that could potentially impact the market's initial reaction to SEO announcements. Our hypotheses are thus to establish whether sentiment is a significant factor in rights issuance, and whether the market timing theory or pecking order theory can explain the reasoning behind issuing equity.

The results reveal that investor sentiment plays no significant role in a firm's decision to conduct a SEO. In addition, a firm's prior abnormal share price performance and marketto-book ratio, which are two other popular measures used to gauge the overevaluation of a share's worth, also bear no significant influence on a firm's decision to issue equity. Thus, there is no concrete evidence of managers attempting to time the market when conducting SEOs. Secondly, an event study is undertaken to study the short-run share performance of firms around the SEO announcement date. In line with the international evidence, a significant negative market reaction is found, with SEO firms experiencing an average two-day cumulative abnormal return (CAR) of $-2.6 \%$ in response to the SEO announcement. Further analysis reveals that the market's reaction to the SEO announcement is in no way significantly influenced by investor sentiment, again casting doubt on the predictions implied by the behavioural models put forth in the literature. Moreover, neither the issuing firm's size, market-to-book ratio and Tobin's Q-ratio nor the size of the equity issue relative to the issuing firm's size significantly influences the market's reaction to the SEO announcement.

The remainder of the article is organised as follows: The 'Literature review' section discusses the relevant literature surrounding SEOs. The 'Data and methodology' section sets out the methodology employed, with the results discussed in the 'Results' section. The 'Conclusion' section concludes the study.

\section{Literature review}

Faced with the puzzle, that is, the capital structure decision, researchers began to pay more attention to studying the market's reaction to SEOs in more detail. The literature has since revealed some fascinating patterns. Smith (1986), using the data from several previous studies, examined the market's reaction to the announcement of SEOs and found an average two-day abnormal share return of $-3.14 \%$ for industrials, and $-0.75 \%$ for utilities. Ritter (2003), also making use of several prior studies, found an average two-day cumulative return of approximately $-2 \%$ around the announcement date.

The adverse selection model developed by Myers and Majluf (1984) appears to be the most commonly cited explanation to explain these negative announcement effects (Ritter 2003). Their model, which focuses on information asymmetries between managers and investors, argues that managers are better informed than investors with respect to the true value of the firm's assets and its growth opportunities. Therefore, in the interest of existing shareholders, managers will only issue equity when they believe that their equity is overvalued. Rational investors are aware of the manager's incentives and therefore interpret the news of share issues as 'bad news' about the firm's intrinsic value (Pilotte 1992).

This explanation raises a serious challenge to strong-form market efficiency as there is overwhelming evidence that managers indeed attempt to time the market, with the incentive to issue equity when it is overvalued. Baker and Wurgler (2002) reported that a firm's capital structure is significantly related to previous market valuations, which implies that a firm's capital structure is a result of its cumulative past attempts to time the market. 
These findings are in line with the extensive body of research documenting the increase in share issuance activity during periods of high market valuations (Jung, Kim \& Stulz 1996). It would make sense that the preferred environment to issue shares is during robust market conditions. DeAngelo et al. (2010) found a significant relationship between the probability of conducting a SEO and common measures of mispricing such as pre-issue abnormal returns, market-to-book ratios and the age of a firm. However, measuring the fundamental value of a share is subjective and another catalyst for widespread debate. Hence, measures of investor sentiment are fast becoming the popular choice for gauging market conditions.

Chou and Lin (2015) found that the probability of a firm conducting a SEO is positively related to investor sentiment, as measured using the investor sentiment index developed by Baker and Wurgler (2006). Not only are firms more likely to issue shares during periods of high investor sentiment, but they also experience less negative announcement effects when announcing the SEO during periods of high investor sentiment. It is argued that investors become overly optimistic during these periods of hyped sentiment, bidding share prices upwards and causing deviations from fundamental values which create incentives for managers to issue equity in an attempt to time the market. This investor over-optimism also explains why investors are reacting less negatively to SEO announcements during periods of high investor sentiment. This weakened negative response during high investor sentiment periods might even create additional incentives for managers to issue shares during these periods, in addition to the incentive already created by the potential overvaluation of their firm's equity.

Not all announcements of equity offerings are interpreted as 'bad news' by the market. The interaction between financing and investing decisions is also a vital consideration, as the announcement of an equity issue can convey multiple facets of information. Not only does it convey information about the possible intrinsic value of the firm, but it also implies that the firm will make use of the funds in its operations (Ritter 2003). Bridging the 'information gap' between investors and managers should influence the market's reaction to SEO announcements.

If investors believe that the cash raised from the equity issue will lead to the firm investing in a project that will add value to the firm, then the announcement effect could be positive or, by extension, less negative. Empirical evidence suggests that there is a less negative reaction to an equity issuance when firms can convince investors that there is a good reason for issuing the equity (Ritter 2003). Jung et al. (1996) provided evidence that firms with a high Tobin's Q-ratio have announcement effects that do not significantly differ from zero. In contrast, Barclay and Litzenberger (1988) failed to establish any significant relationship between announcement effects and either the Tobin's Q-ratio or the intended use of funds.
Korajczyk, Lucas and McDonald (1992) found evidence that the announcement effects associated with equity issues are less negative when the announcement is made shortly after an earnings report is issued, arguing that during this time period there is less information asymmetry. Choe, Masulis and Nanda (1993) found that negative announcement effects are diminished when the economy is in an expansionary phase, which is arguably when there may be reduced adverse selection risk.

Furthermore, studies have shown that private equity issue announcements have a positive announcement effect, with share prices increasing in response to said announcements (Kato \& Schallheim 1993). This result is again consistent with information asymmetry as it can also be argued that private equity issues are less susceptible to information asymmetries.

In a similar manner, investors might fear that the cash raised from the equity issue might be misused by the firm's managers in value-destroying behaviour resulting from 'empire building' or 'managerial hubris'. Thus, agency problems could potentially compound the negative announcement effect. Jung et al. (1996) found evidence that firms with inferior managerial ownership, who are arguably more susceptible to the agency problems described above, have more negative price reactions to announcing the issue of new shares. Huang and Chiu (2017) considered the impact of insider trading on SEO performance for the Taiwanese market and found that insider trading leads to overvaluation of SEO announcing firms, leading to negative abnormal returns after the announcement. In other words, the SEO announcement signals overvaluation of the firm rather than growth potential. This sentiment is echoed by Ali (2016) who provided similar evidence that SEO announcements signal overvaluation as opposed to growth potential. The author's findings lend credence to the market timing hypothesis.

Although the implications of the market timing theory in conjunction with the adverse selection model are well suited in explaining the negative announcement effects of SEOs, this does not necessarily mean that timing the market is the most dominant motive for issuing equity. All else equal, firms should predominantly issue equity out of the necessity to raise funds. There is also the school of thought that the expansion of a firm naturally leads to the point where the firm needs to issue more shares, which is simply a by-product of the firm's lifecycle stage.

Kim and Weisbach (2008), who studied SEOs across 38 nonAfrican countries, found that the primary reason for firms issuing new shares was to raise funds to appease the nearterm necessity for cash. They found that both the market timing theory and the stage of a firm's lifecycle only play a role as secondary considerations. These results are echoed in the findings of DeAngelo et al. (2010), who also found that both the market timing and lifecycle theories played a secondary role, with the primary consideration being the 
need for short-term cash. Moreover, the authors found that the lifecycle effect was quantitatively stronger in explaining the SEO decision when compared to the market timing effect, after finding that a large majority of firms with potential market timing opportunities failed to take advantage of them.

Finally, there are those that question the efficacy of announcement effect analysis based on various arguments. Firstly, the measure of abnormal market returns is subjective with respect to the benchmark employed. Secondly, announcement effect analysis is framed in such a manner that it can attempt to measure the stock market's reaction to the announcement, which is assumed to be unexpected. If investors had any prior expectation of the announcement occurring, then the recorded announcement effect surrounding the day of the announcement would be vastly underestimated (Ritter 2003). Nonetheless, it is impossible to test the expectations of the entire market. Thus, a common assumption must be made that these announcements are indeed unexpected. Thirdly, sometimes the most simple and logical explanations are overlooked. Basic economics and the law of supply and demand predict that an increase in the supply of a good will lead to a decrease in the price of that good. Thus, the negative stock market reaction to the issue of new shares should be at least partially explained by the law of supply.

In summary and in light of all the evidence, it is the adverse selection model, which describes the awareness of investors with respect to the manager's incentives to issue overvalued equity, which has emerged as the most prevalent theory in explaining SEOs (Chou \& Lin, 2015). There is a barrier separating the information flow between investors and managers. Hence, even if managers are issuing shares for no other reason than to raise cash for operational activity, investors have reasonable doubt regarding the intentions of managers. This reasoning is what makes the adverse selection model the popular explanation for the market's generally negative reaction to SEO announcements. In addition, firms can potentially mitigate these negative announcement effects by credibly communicating favourable reasoning behind the need for an equity raise.

It is also important to note that there are numerous, not necessarily mutually exclusive, motivations for issuing equity that can be broadly summarised into three categories: (1) to finance investments or operations, (2) to transfer wealth from new shareholders to existing shareholders and (3) to increase liquidity for both the firm and the insiders (Kim \& Weisbach 2008). Firms may have different motives for issuing shares but the logic that a preference would still exist for issuing shares during periods of high market valuations and robust market conditions is difficult to refute.

A major motivation behind this study was the lack of research conducted in South Africa with respect to the long-run performance of SEO firms. Instead, most of the existing, relevant South African literature focuses on IPOs and the capital structure decision as a whole. In line with international evidence, South African studies have also found evidence of
IPO underperformance on the JSE. Therefore, even though the topic of SEOs has been largely ignored in the South African context, it might be reasonable to assume that the international patterns found surrounding SEOs would also be found in the South African context as the international evidence suggests that similar trends found in IPOs are also found in SEOs.

Auret and Britten (2008) examined the post-issue operating performance of IPOs on the JSE and found that issuing firms experienced an increase in their profitability (as captured by returns on assets), leading up to the IPO which was then followed by significant declines in profitability in the third year subsequent to the IPO. The authors cited their findings as evidence in support of the market timing theory and the possible tendency of managers to overinvest.

Chipeta and Jardine (2014) reported findings of a significantly negative relationship between the volume of IPOs and longrun performance, as well a significantly negative relationship between pre-IPO revenue forecasts and subsequent postissue operating performance. Their findings suggest that the IPO market in South Africa is affected by the 'fads and overoptimism' theory suggested by Ritter (1991).

Finally, Dalika and Seetharam (2015) further highlighted the importance of investor sentiment in the South African context by providing evidence that investor sentiment has a strong impact on share returns on the JSE. Their results suggest that during low sentiment periods, shares that are more sensitive to sentiment experience higher returns, a pattern that fully reverses in periods of high sentiment. The authors measured investor sentiment using the investor sentiment index developed by Baker and Wurgler (2006), which they adapted to the JSE.

\section{Data and methodology Sample and data collection}

Secondary equity offering announcements were found using the INET BFA Expert database, which has a record of all the relevant Stock Exchange News Service (SENS) announcements for all listed and delisted firms on the JSE during the period 1998-2015. The following keywords were used in the search: accelerated book-build, equity raises, new ordinary shares, new shares and rights offers. The sample period does not precede 1998 because of restrictions on the availability and reliability of the announcements prior to 1998. Only announcements relating solely to the issue of new shares for cash are included in the sample.

Financial and utility firms were excluded from the sample. Firms that make multiple issues within a five-year period were included in the sample, and if a firm makes multiple announcements within a five-year period, the first announcement is used. Share price data, firm characteristics, accounting ratios and the inputs for the asset pricing model were gathered from the INET BFA Expert database as well as 
from the Findata@Wits database. Finally, the analysis in this study involves the common assumption that the SEO announcements collected represent the release of new, previously unexpected information to the public. Our sample size thus consists of 152 announcements conducted by 79 firms.

\section{Description of overall research design}

\section{Measuring investor sentiment}

Investor sentiment is measured using the yearly marketbased investment sentiment index constructed by Baker and Wurgler (2006). Dalika and Seetharam (2015) adapted this index for South Africa, which led to the following index being developed in their study:

$$
\begin{aligned}
\text { SENTIMENT } & =0.623 \text { NIPO }+0.451 \text { RIPO } \\
& +0.482 \text { Premium }+0.420 T U R N
\end{aligned}
$$

where annual investor sentiment (SENTIMENT) is compiled using four measures: (1) the number of IPOs issued during the year (NIPO), (2) the average first-day returns of IPOs issued during the year (RIPO), (3) the volatility premium (Premium) and (4) the JSE share turnover (TURN). The volatility premium is measured as the year-end log ratio of the value-weighted average market-to-book ratio of high volatility shares divided by that of low volatility stocks, where the top (bottom) three volatility deciles represent the high (low) volatility shares; and turnover is the log of total market turnover (the total rand volume of shares traded over the year) divided by the total market capitalisation of the JSE at the end of the previous year (Dalika \& Seetharam, 2015). Similar to Chou and Lin (2015), high (low) investor sentiment periods are defined as the years that the investor sentiment index is above (below) its median during the sample period 1998-2015.

This study m used logit regression models to test the impact of investor sentiment on SEO probability using the procedure applied by DeAngelo et al. (2010) to calculate standardised market-to-book ratios and market-adjusted share returns. The logit model for SEO probability is specified as:

$$
\begin{aligned}
S E O_{i t} & =\alpha+\beta_{1} S_{E N T_{t}}+\beta_{2} \frac{M}{v_{i t}}+\beta_{3} \text { PriorR }_{i t} \\
& +\beta_{4} \text { FutureRT }_{i t}+\beta_{5} \text { Age }_{i t}+\varepsilon_{i t}
\end{aligned}
$$

[Eqn 2]

where $S E O_{i t}$ is a dummy variable (which is equal to 1 if firm $i$ conducts a SEO in year $t$, and zero if not); SENT is the yearly sentiment index in year $t ; M / B_{i t}$ is the standardised market-tobook ratio for firm $i$ in year $t$ (calculated as the raw market-tobook ratio at the end of the previous year divided by the median market-to-book ratio for all firms listed on the JSE at the end of the previous year); Prior $R T_{i t}$ is the market-adjusted share return for firm $i$ over the 12 or 36 months ending immediately before the year $t$; Future $R T_{i t}$ is the marketadjusted return for firm $i$ over the 12 or 36 months starting immediately after the year $t$; and $A g e_{i t}$ is the number of years that the firm $i$ has been listed on the JSE in year $t$. Ceteris paribus, a positive sign is expected for $\beta_{1}$ implying that investor sentiment positively influences a firm's SEO decision. $\varepsilon_{i t}$ is the error term. The regression analysis is limited to firms with all the available relevant information and is analysed first using the returns over a 12-month period and then repeated using the returns over a 36-month period.

\section{Announcement effects}

\section{Event study analysis}

Firstly, an event study is undertaken in order to determine the market's short-term reaction to the SEO announcement, using the market-adjusted returns model (assuming a $\beta$ of one and $\alpha$ of zero) to estimate abnormal performance (Brown \& Warner, 1985). Despite the simplicity of this model, more complicated models have not necessarily proven more robust (Jones, Danbolt \& Hirst 2004). The market-adjusted abnormal returns are calculated as follows:

$a r_{i t}=r_{i t}-r_{i e}$

where

$a r_{i t}=$ abnormal return on share $i$ on day $t$ (where day $t$ is the issuing day)

$r_{i t}=$ return on share $i$ on day $t$

$r_{i e}=$ return on the JSE All Share Index on day $t$.

Alternatively, this study uses (1) the share's 10-day average return (prior to the announcement date) and (2) its pre-issue 10-day maximum return.

Then, two separate portfolios are formed for SEOs issuing during high sentiment periods and those issuing during low sentiment periods. The equally weighted average abnormal returns of a portfolio of $n$ shares on day $t$ (where day $t=0$ is the issuing day) are calculated as follows:

$$
A R_{t}=\frac{1}{n} \sum_{i=1}^{n} a r_{i t}
$$

Finally, the CAR is calculated from day $k$ to day $m$ (the summation of the average abnormal returns within each portfolio):

$$
C A R_{(k, m)}=\sum_{t=m}^{n} A R_{t}
$$

The CARs of the high-sentiment portfolio and the lowsentiment portfolio are compared. Ceteris paribus, the highsentiment portfolio is expected to have a less negative CAR.

\section{Regression analysis}

Subsequently, OLS regression analysis is undertaken in order to investigate the impact of both the firm characteristics and 
the announcement details on the share's short-run performance following the SEO announcement:

$$
\begin{aligned}
a r_{i t} & =\alpha+\beta_{1} \text { YearsL }_{i, t}+\beta_{2} \text { Qratio }_{i, 1-t} \\
& +\beta_{3} \text { IssueSize }_{i, t}+\beta_{4} \text { size }_{i, t}+\varepsilon_{i, t}
\end{aligned}
$$

where $a r_{i, t}$ is the abnormal return on share $i$ at time $t$; Years $L_{i, t}$ is the number of years that firm $i$ has been listed at time $t$; Qratio $_{i, 1-t}$ is a dummy variable (which is equal to 1 if firm $i^{\prime} \mathrm{s}$ Tobin's Q-ratio, the year prior to announcing the SEO, exceeds 1, and zero if not); IssueSize ${ }_{i t}$ represents the size of the issue relative to the size of firm $i$ at time $t ; S_{i z e}$ is the size of firm $i$ at time $t$; and $\varepsilon_{i t}$ is the error term.

\section{Results}

The results are divided into two sections. The first section examines the market's reaction to SEO announcements, in addition to exploring the potential influences on the market's reaction to these announcements. The second section explores the influence of investor sentiment, and other explanatory variables, on the probability of a firm conducting a SEO.

\section{Investor sentiment and the probability of secondary equity offerings}

\section{The summary statistics}

Figure 1 shows the annual investor sentiment plotted against the median investor sentiment from 1998 to 2015, with points above (below) the median indicating periods of high (low) investor sentiment. An interesting, expected pattern emerges with investor sentiment peaking prior to the 2008 global financial crisis, followed by a sharp descent illustrating the spillover effect of the US housing crisis. This is followed by a gradual 'recovery' of investor sentiment in South Africa. This is a clear illustration that investor sentiment is not only driven by conditions in the domestic economy but also by international events. While anomalous events may cause exaggerated spikes and declines in investor sentiment that has the potential to skew results, an aim of this study is to examine the impact of investor sentiment on the performance

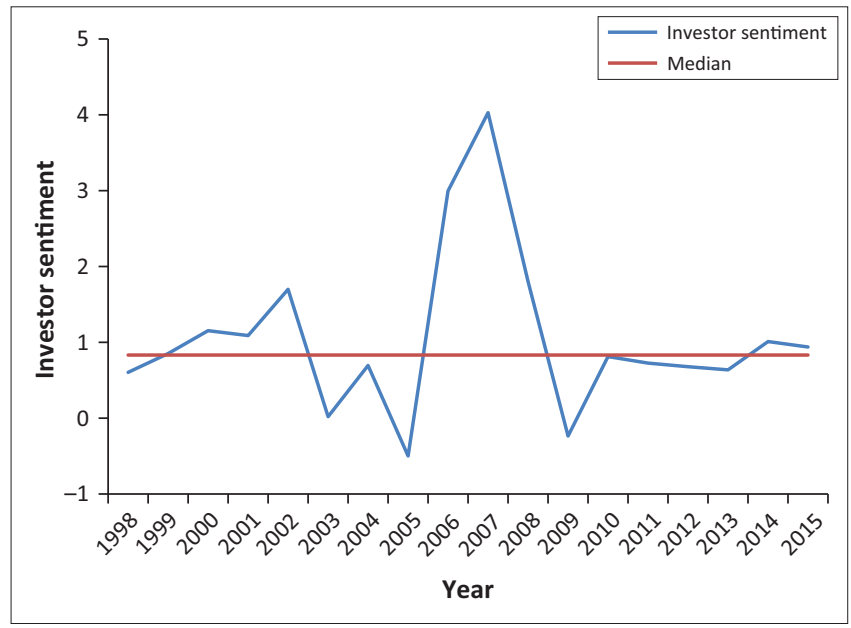

Source: Dalika, N. \& Seetharam, Y., 2015, 'Sentiment and returns: An analysis of investo sentiment in the South African market', Investment Management \& Financial Innovations 12(1), 267-276

FIGURE 1: The investor sentiment index from Dalika and Seetharam (2015). of SEO firms. Therefore, by controlling for investor sentiment, the results of this study provide an added layer of reliability.

The summary statistics for investor sentiment, prior marketadjusted share returns, future market-adjusted share returns, standardised market-to-book ratios and the years listed are presented in Table 1. The mean and median of the investor sentiment index are both relatively close to 1 , indicating that investor sentiment is slightly tending towards higher levels during the sample period. All else considered, a mean and median of zero would have indicated that investor sentiment would not be inclining towards either high or low levels over the sample period. This illustrates the derived benefit of defining high- and low investor sentiment periods as relative to the sample period, as opposed to assuming that the average investor sentiment levels are zero.

The average age of the sample firms included in the logit regression is approximately 21.5 years, whilst future and past returns are fairly symmetric, indicating that any possible long-run SEO underperformance would not be attributed to market conditions. This hypothesis is tested in a subsequent study. The extreme skewness and kurtosis of the variables used in the regression analysis fall in line with the relevant existing literature (Chou \& Lin 2015).

\section{Regression analysis}

Table 2 reports the regression analysis surrounding the decision to conduct SEOs. Similar to the findings of Chou and Lin (2015), the probability of a firm conducting a SEO is significantly negatively related to the number of years listed and the future share return. This falls in line with the international evidence, suggesting that firms conducting SEOs underperform with regard to future share returns (Loughran \& Ritter 1995). Moreover, the implication of younger firms being more likely to conduct SEOs fits the narrative of the market timing theories, which suggest that the shares of younger firms are more susceptible to misvaluations, ultimately increasing the incentive to issue shares.

Contradictory to the popular market timing explanation, regressions $\mathrm{A}-\mathrm{H}$ indicate that there does not seem to be any significant relationship between a firm's market-to-book ratio or prior abnormal share return and the probability that a firm conducts a SEO. In fact, there appears to be a negative, albeit, non-significant relationship between these variables. Therefore, there does not appear to be any signs that the firms conducting SEOs are attempting to take advantage of high market valuations or previously high abnormal returns.

As shown in the results of regressions E-I, investor sentiment has a positive, but insignificant influence on the probability of a firm conducting a SEO. Although there are more SEOs during high investor sentiment periods compared to low investor sentiment periods (as shown in Table 5), investor sentiment does not appear to significantly influence management's decision to issue new shares. 
TABLE 1: Summary statistics.

\begin{tabular}{|c|c|c|c|c|c|c|}
\hline Variables & Mean & Median & SD & Skewness & Kurtosis & \#Obs \\
\hline Sentiment index & 1.084 & 0.857 & 1.089 & 1.435 & 2.844 & 18 \\
\hline Years listed & 21.491 & 14.000 & 19.86 & 1.367 & 1.029 & 2835 \\
\hline $\begin{array}{l}\text { Standardised } \\
\text { M/B ratio }\end{array}$ & 2.561 & 1.000 & 42.828 & 45.912 & 2339.36 & 2835 \\
\hline PriorRT12 (\%)† & 1.325 & 1.179 & 1.450 & 20.432 & 607.787 & 2835 \\
\hline PriorRT36 $(\%)^{\dagger}$ & 2.132 & 1.431 & 3.075 & 7.380 & 79.694 & 2835 \\
\hline FutureRT12 (\%)† & 1.338 & 1.174 & 1.415 & 20.826 & 651.458 & 2835 \\
\hline $\begin{array}{l}\text { FutureRT36 } \\
(\%)^{+}\end{array}$ & 2.140 & 1.522 & 2.965 & 7.939 & 90.834 & 2835 \\
\hline
\end{tabular}

$\mathrm{M} / \mathrm{B}$ ratio, market to book ratio; \#Obs, number of observations; SD, standard deviation.

$\dagger$, All prior and future share returns are calculated using the cumulative monthly returns of the entire window period.

TABLE 2: Regression analysis on the decision to conduct secondary equity offerings.

\begin{tabular}{|c|c|c|c|c|c|c|}
\hline Variable & Intercept & Investor sentiment & $\mathrm{M} / \mathrm{B}$ ratio & Prior share return & Future share return & Years listed \\
\hline \multicolumn{7}{|c|}{ Regression A: All firms with 12-month prior and future returns } \\
\hline Coefficient & $-2.023 * * *$ & - & -0.009 & -0.289 & $-1.477 * * *$ & - \\
\hline \multicolumn{7}{|c|}{ Regression B: All firms with 36-month prior and future returns } \\
\hline Coefficient & $-2.846 * * *$ & - & -0.002 & $-0,021$ & $-0.765 * * *$ & - \\
\hline \multicolumn{7}{|c|}{ Regression C: All firms with years listed included (with 12-month prior and 12 month-future returns) } \\
\hline Coefficient & $-1.805^{* * *}$ & & -0.008 & -0.268 & $-1.377 * * *$ & $-0.019 * *$ \\
\hline \multicolumn{7}{|c|}{ Regression D: All firms with years listed included (with 36-month prior and 36-month future returns) } \\
\hline Coefficient & $-2.499 * * *$ & - & -0.002 & -0.023 & $-0.724 * * *$ & $-0.021 * *$ \\
\hline \multicolumn{7}{|c|}{ Regression E: All firms with investor sentiment included (with 12-month prior and 12-month future returns) } \\
\hline Coefficient & $-1.411 * * *$ & 0.048 & -0.004 & -0.117 & $-0.533^{* * *}$ & - \\
\hline \multicolumn{7}{|c|}{ Regression F: All firms with investor sentiment included (with 36-month prior and 36-month future returns) } \\
\hline Coefficient & $-1.752 * * *$ & 0.071 & -0.001 & -0.017 & $-0.259 * * *$ & - \\
\hline \multicolumn{7}{|c|}{ Regression G: All firms with investor sentiment and years listed included (with 12-month prior and 12-month future returns) } \\
\hline Coefficient & $-2.007^{* * *}$ & 0.121 & -0.009 & -0.286 & $-1.293^{* * *}$ & $-0.020 * *$ \\
\hline \multicolumn{7}{|c|}{ Regression H: All firms with investor sentiment and years listed included (with 36-month prior and 36-month future returns) } \\
\hline Coefficient & $-1.607^{* * *}$ & 0.076 & -0.001 & -0.018 & $-0.249 * * *$ & $-0.009 * *$ \\
\hline
\end{tabular}

**, Significance at the $5 \%$ level; $* * *$, significance at the $1 \%$ leve

One imperative consideration to make when analysing the results in this section is the significantly smaller proportion of firms conducting SEOs in South Africa, relative to both the total general population of listed firms in South Africa and the number of firms conducting SEOs in the United States. To put this into context, the sample in this study includes 152 SEO announcements compared to the 2835 total firmyear observations included in the logit regressions. Thus, the small sample size would naturally present a challenge to finding any significant results in the logit regression analysis. This point is further illustrated by the unreported, low R-squared values across all eight regression models, indicating the inadequacies of the explanatory variables in explaining a firm's decision on whether or not to conduct a SEO. Therefore, the decision to issue equity is poorly explained by the explanatory variables used in all eight regression models.

In summary, although it would make sense that more corporate activity takes place during periods of high investor sentiment, there is no significant evidence that firms conducting SEOs are attempting to time the market. This contradicts the market timing theory and the findings of previous international literature that analyse the relationship between investor sentiment and SEOs (Chou \& Lin 2015; DeAngelo et al. 2010). These results were hindered by restrictions on the sample size.

\section{The stock market's reaction to secondary equity offering announcements}

\section{Event study analysis}

The sample covers 152 SEO announcements made by 79 firms, with 81 announcements occurring during periods of high investor sentiment in contrast to the 71 announcements occurring during periods of low investor sentiment. Further analysis of the sample and its observable patterns are discussed in subsequent sections, with this section focusing on the market's reaction to the SEO announcements.

Table 3 reports the results of the share price movements in response to the SEO announcements. The average actual return and abnormal return on the day of the SEO announcement are both $-2.7 \%$. Moreover, qualitatively and quantitatively in line with the findings of Ritter (2003), the average 2-day CAR following a SEO announcement is $-2.6 \%$. The market reacts in a similarly negative manner when measuring the 1-day abnormal share returns as well as the actual cumulative 2-day share returns following the SEO announcement. Across the four measures used, it is clear that the majority of SEO announcements are met with a negative response from the market as illustrated in the last column of Table 3. We estimate the returns in Table 3 again, using 10 days as the event window, with similar results presented in Table 4 . 
In further support of these findings, the median values are also significantly negative across the board. Overall, these findings are in line with the adverse selection model developed by Myers and Majluf (1984) predicting a negative share price reaction to SEO announcements, adding to the vast amount of confirmatory international evidence. These findings are robust to the different measures of abnormal returns used in this study as well as across industries (results not reported here).

\section{Regression analysis}

This section attempts to better understand and explain the market's generally negative reaction to SEOs.

Table 5 presents the results of the regression analysis. Across the four regressions, there is no confirmatory evidence that markets react more negatively to SEO announcements conducted by younger firms (firms that have been listed on the JSE for a shorter amount of time). Similarly, the market's reaction does not seem to be significantly influenced by either the size of a firm or by the relative issue size, with all the above-mentioned coefficients being insignificant and approximately equal to zero. As expected, there is a slightly positive relationship between the market's reaction to the

TABLE 3: The stock market's reaction to secondary equity offering announcements.

\begin{tabular}{lccccc}
\hline Variable & Mean & Median & \#Obs. & SD & Neg/Pos \\
\hline One-day raw return & $-0.027^{* * *}$ & $-0.017^{* * *}$ & 152 & 0.042 & $108 / 13$ \\
$\begin{array}{l}\text { Two-day cumulative } \\
\text { raw return }\end{array}$ & $-0.026^{* * *}$ & $-0.009^{* * *}$ & 152 & 0.090 & $86 / 41$ \\
$\begin{array}{l}\text { One-day abnormal } \\
\text { return }\end{array}$ & $-0.027^{* * *}$ & $-0.015^{* * *}$ & 152 & 0.041 & $130 / 22$ \\
$\begin{array}{l}\text { Two-day cumulative } \\
\text { abnormal return }\end{array}$ & $-0.026^{* * *}$ & $-0.012^{* * *}$ & 152 & 0.090 & $101 / 51$ \\
\hline
\end{tabular}

\#Obs, number of observations; Neg/Pos, ratio of negative to positive announcements; $\mathrm{SD}$, standard deviation.

**, Significance at the $5 \%$ level; ${ }^{* * *}$, significance at the $1 \%$ level

TABLE 4: The stock market's reaction to secondary equity offering announcements.

\begin{tabular}{|c|c|c|c|c|c|}
\hline Variable & Mean & Median & \#Obs & SD & Neg/Pos \\
\hline \multicolumn{6}{|c|}{ Panel A: Using the share's prior 10-day average as a benchmark } \\
\hline One-day return & $-0.026 * * *$ & $-0.014 * * *$ & 149 & 0.042 & $111 / 27$ \\
\hline $\begin{array}{l}\text { Two-day } \\
\text { cumulative return }\end{array}$ & $-0.024 * * *$ & $-0.014 * * *$ & 149 & 0.090 & $88 / 51$ \\
\hline \multicolumn{6}{|c|}{ Panel B: Using the share's prior 10-day maximum as a benchmark } \\
\hline One-day return & $-0.097 * * *$ & $-0.063 * * *$ & 149 & 0.042 & $134 / 3$ \\
\hline $\begin{array}{l}\text { Two-day } \\
\text { cumulative return }\end{array}$ & $-0.165 * * *$ & $-0.101 * * *$ & 149 & 0.090 & $132 / 6$ \\
\hline
\end{tabular}

\#Obs, number of observations; Neg/Pos, ratio of negative to positive announcements; SD, standard deviation.

**, Significance at the $5 \%$ level; $* * *$, significance at the $1 \%$ level
SEO announcements and the Tobin's Q-ratio of the issuing firm (which is a proxy for the perceived quality of a firm's investment opportunities). However, the coefficient is also insignificant across all four regression models.

The failure of the four regression models to find any significant relationships between the market's reaction to the SEO announcements and the popular explanatory variables set out by previous literature is further highlighted by the extremely low $R$-squared values across the regression models. These findings are in line with the results of Barclay and Litzenberger (1988), who also reported that neither the issue size nor the expected profitability of a firm's planned investments (also measured using Tobin's Q-ratio) had any significant influence on SEO announcement effects.

Overall, the results indicate that none of the proposed explanatory variables display any significant influences on the market's reaction to SEO announcements. In fact, these variables perform poorly in attempting to explain the market's reaction. The relative issue size, age of the firm, size of the firm and the firm's Tobin's Q-ratio do not significantly impact the market's reaction to the SEO announcement. None of these variables appear to either mitigate or exacerbate the market's generally negative perception of SEO announcements.

\section{Investor sentiment and secondary equity offering announcements}

As illustrated in Figure 2, the annual amount of SEO announcements issued peaked in 2007 and remained relatively high for the following few years. Despite the obvious peak in 2007 and a few other high (low) issue periods which coincide with high (low) investor sentiment periods, there seems to be a reasonably stable flow of announcements across the years, irrespective of investor sentiment. No clear-cut pattern emerges to reliably signal that the peaks and troughs in issuing activity are undeniably influenced by investor sentiment. For example, the second highest period of SEO announcements occurred in 2009, a period corresponding to low investor sentiment. Figure 2 is a near-perfect illustration confirming the results which failed to establish a significant relationship between investor sentiment and the probability of a firm conducting a SEO.

Nevertheless, there are more SEO announcements during periods of high investor sentiment (81) relative to the

TABLE 5: Event study regression analysis.

\begin{tabular}{|c|c|c|c|c|c|c|}
\hline Variable & Intercept & Years listed & Q-ratio & Issue size & Size & $R^{2}$ \\
\hline \multicolumn{7}{|c|}{ Regression 1: 1-day actual return } \\
\hline Coefficient & $-0.031 * * *$ & 0.000 & 0.006 & 0.000 & 0.000 & 0.010 \\
\hline \multicolumn{7}{|c|}{ Regression 2: 2-day actual cumulative return } \\
\hline Coefficient & -0.025 & 0.000 & 0.003 & 0.000 & 0.000 & 0.022 \\
\hline \multicolumn{7}{|c|}{ Regression 3: 1-day abnormal return } \\
\hline Coefficient & $-0.032 * * *$ & 0.000 & 0.009 & 0.000 & 0.000 & 0.037 \\
\hline \multicolumn{7}{|c|}{ Regression 4: 2-day abnormal cumulative return } \\
\hline Coefficient & -0.026 & 0.000 & 0.003 & 0.000 & 0.000 & 0.060 \\
\hline
\end{tabular}

${ }^{* *}$, Significance at the $5 \%$ level; ${ }^{* * *}$, significance at the $1 \%$ level 


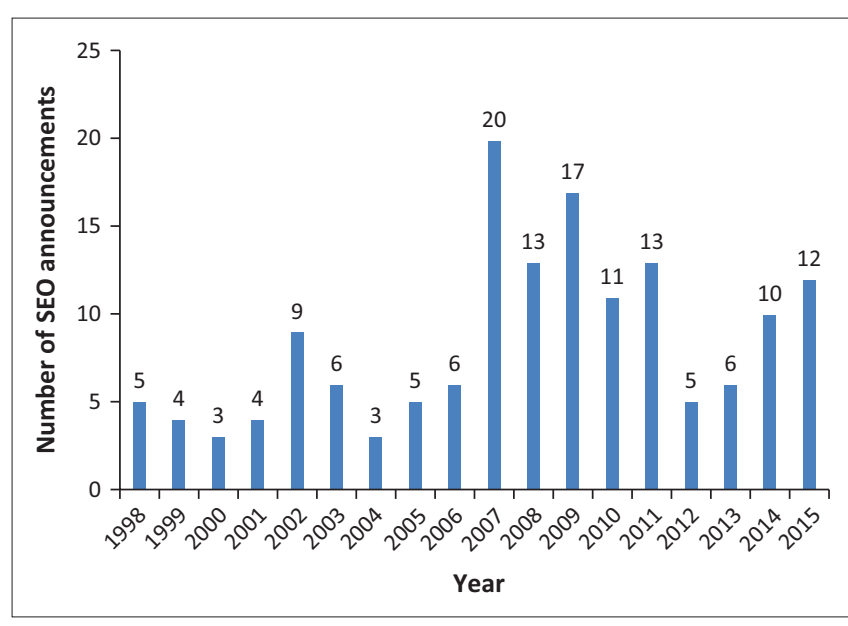

SEO, secondary equity offering.

FIGURE 2: Secondary equity offering announcements across the sample period.

TABLE 6: Investor sentiment and the stock market's reaction to secondary equity offering announcements.

\begin{tabular}{lccccc}
\hline Variable & $\begin{array}{c}\text { SEOs during } \\
\text { high- } \\
\text { sentiment } \\
\text { periods (1) }\end{array}$ & \#Obs & $\begin{array}{c}\text { SEOs during } \\
\text { low- } \\
\text { sentiment } \\
\text { periods (2) }\end{array}$ & \#Obs & $\begin{array}{c}\text { Difference } \\
\text { (1)-(2) }\end{array}$ \\
\hline $\begin{array}{l}\text { One-day raw } \\
\text { return }\end{array}$ & $-0.027^{* * *}$ & 81 & $-0.026^{* * *}$ & 71 & -0.001 \\
$\begin{array}{l}\text { Two-day } \\
\text { cumulative } \\
\text { raw return }\end{array}$ & $-0.022^{* * *}$ & 81 & $-0.030^{* * *}$ & 71 & 0.008 \\
$\begin{array}{l}\text { One-day } \\
\text { abnormal } \\
\text { return }\end{array}$ & $-0.026^{* * *}$ & 81 & $-0.027^{* * *}$ & 71 & 0.001 \\
$\begin{array}{l}\text { Two-day } \\
\text { cumulative } \\
\text { abnormal } \\
\text { return }\end{array}$ & $-0.021^{* * *}$ & 81 & $-0.031^{* * *}$ & 71 & 0.010 \\
$\begin{array}{l}\text { SEO, secondary equity offering; \#Obs, number of observations. } \\
* *, \text { Significance at the } 5 \% \text { level; ***, significance at the } 1 \% \text { level }\end{array}$ & & \\
\end{tabular}

announcements made during periods of low investor sentiment (71), as shown in Table 6. This table reports the difference in share price movements for firms issuing during different periods of investor sentiment. Ceteris paribus, it is expected that the stock market would react less negatively to SEO announcements during periods of high investor sentiment. However, the results find no significant differences between the share price movements of firms conducting SEOs during periods of low investor sentiment vis-à-vis firms conducting SEOs during periods of high investor sentiment.

Although firms conducting SEOs during high-sentiment periods, on average, experience a less negative two-day abnormal cumulative return of approximately $1 \%$ when compared to their low-sentiment period counterparts, this difference is insignificant. These results are confirmed when analysing the alternative measures of abnormal share price returns, with no indication of any significant differences across the board. The market appears to react slightly less negatively to SEO announcements made during periods of high investor sentiment in terms of magnitude (with exception of the 1-day actual raw returns). However, none of these differences are significant.

In summary, investor sentiment does not appear to significantly influence the short-term performance of firms conducting SEOs. Contradictory to predictions set forth by the market timing theory, the market does not appear to react significantly less negatively to the SEO announcements made during periods of high investor sentiment. These results fail to establish the added incentive of issuing SEOs during periods of high investor sentiment, as documented in the previous international literature (Chou \& Lin 2015).

\section{Summary of the results}

Analysis of SEO announcement effects provides evidence that is consistent with the adverse selection model pioneered by Myers and Majulf (1984). The market, on average, reacts negatively to SEO announcements with a statistically significant average 2-day CAR of $-2.6 \%$, following the announcement. The regression analysis further reveals that the market's reaction to the SEO announcement is not significantly influenced by either the firm's size, Tobin's Q-ratio and marketto-book ratio or the relative size of the equity issue. Similarly, investor sentiment bears no substantial impact on the market's initial reaction to the news that a firm is conducting a SEO.

Overall, these results provide no evidence consistent with the behavioural explanations, particularly those involving market timing considerations that attempt to describe the long-run performances of issuing firms. Instead, the results are consistent with the rational framework whereby any differences in returns between issuing and non-issuing firms are sufficiently explained by the variation in market risk.

\section{Conclusion}

While the market's typically negative reaction to SEO announcements appears to be well explained by the adverse selection model developed by Myers and Majluf (1984), the widely documented poor long-run performance of issuing firms, for periods reaching up to five years after issuance, has been far more difficult to explain. Opinions have been divided on whether there is a rational explanation to this phenomenon or whether the explanation lies within the behavioural intricacies attributed to stock market participants. Despite the importance of these findings and the potential benefits of understanding the market's reaction to SEOs, the topic has until now been widely ignored by the South African literature. As a result, this study set out to explore the shortrun performance of SEOs on the JSE.

Firstly, the initial decision on whether or not a firm conducts a SEO was analysed using regression analysis. The findings revealed that investor sentiment, a firm's prior abnormal returns and a firm's market-to-book ratio all bear no significant influence on a firm's decision on whether or not to conduct a SEO. This result casts the first shadow of doubt on the ability of the market timing theory in explaining the performance of SEOs on the JSE. The market timing theory, the popular centrepiece of the behavioural finance theories relevant to SEOs, hypothesises that managers would attempt to issue equity during periods of high investor sentiment, when share prices are more likely to experience overevaluation. 
Although a firm's prior abnormal share performance and market-to-book ratios, which are other popular proxies of share price misvaluation, should also influence the market timing ability of managers, no such evidence was found.

Secondly, an event study was undertaken in order to investigate issuing firms' short-run share performance subsequent to the SEO announcement. The analysis revealed that the market reaction to SEO announcements is generally negative, with an average two-day CAR of $-2.6 \%$. These findings are consistent with the adverse selection model set forth by Myers and Majulf (1984), and are quantitatively and qualitatively similar to the majority of the existing SEO literature. Investors are generally sceptical of a firm's motivation behind the issue of new shares and therefore react negatively to the SEO announcements. One must also not overlook the dilution effect, which is related to the law of supply. The mere action of increasing the number of shares in issue should also naturally create downward price pressure.

Furthermore, neither the issuing firm's size, market-to-book ratio and Tobin's Q-ratio nor the size of the equity issue relative to the issuing firm's size shows any significant influence on the market's reaction to the SEO announcement. These factors do not appear to either alleviate or aggravate the market's generally negative initial reaction to SEO announcements. Further analysis of the short-run share performance of SEOs also reveals that the market's reaction to the announcements is not significantly influenced by investor sentiment. Ceteris paribus, it was expected that investors would react less negatively to the SEO announcement during periods of high investor sentiment, but no such significant benefit was found for firms issuing shares during these periods.

\section{Acknowledgements Competing interests}

The authors declare that they have no financial or personal relationships which may have inappropriately influenced them in writing this article.

\section{Authors' contributions}

Y.S. extracted this article from the Master's research conducted by J.A.d.C. and reviewed the manuscript. Both authors conceptualised the idea and J.A.d.C. executed it.

\section{References}

Ali, H., 2016, 'Behavioural timing, valuation and post-issue performance of UK rights issues', Journal of Accounting 6(1), 1-20.

Auret, C.J. \& Britten, J., 2008, 'Post-issue operating performance of firms listing on the JSE', Investment Analysts Journal 37(68), 21-29.

Baker, M. \& Wurgler, J., 2002, 'Market timing and capital structure', The Journal of Finance 57(1), 1-32. https://doi.org/10.1111/1540-6261.00414

Baker, M. \& Wurgler, J., 2006, 'Investor sentiment and the cross section of stock returns', The Journal of Finance 61(4), 1645-1680. https://doi.org/10.1111/ j.1540-6261.2006.00885.x

Barclay, M.J. \& Litzenberger, R.H., 1988, 'Announcement effects of new equity issues and the use of intraday price data', Journal of Financial Economics 21(1), 71-99. https://doi.org/10.1016/0304-405X(88)90032-3

Chipeta, C. \& Jardine, A., 2014, 'A review of the determinants of long run share price and operating performance of initial public offerings on the Johannesburg Stock Exchange', International Business \& Economics Research Journal (IBER) 13(5), 1161-1176. https://doi.org/10.19030/iber.v13i5.8782

Choe, H., Masulis, R.W. \& Nanda, V., 1993, 'Common stock offerings across the business cycle: Theory and evidence', Journal of Empirical Finance 1(1), 3-31. https://doi.org/10.1016/0927-5398(93)90003-A

Chou, R.K. \& Lin, C.B., 2015, Investor sentiment, market timing and seasoned equity offering, SSRN Working paper.

Dalika, N. \& Seetharam, Y., 2015, 'Sentiment and returns: An analysis of investor sentiment in the South African market', Investment Management \& Financial Innovations 12(1), 267-276.

DeAngelo, H., DeAngelo, L. \& Stulz, R.M., 2010, 'Seasoned equity offerings, market timing, and the corporate lifecycle', Journal of Financial Economics 95(3), 275-295. https://doi.org/10.1016/j.jfineco.2009.11.002

Huang, H.C. \& Chiu, H.H., 2017, 'Insider trading and the classification of seasoned equity offerings: Evidence from Taiwan', International Journal of Economics and Finance 9(5), 58. https://doi.org/10.5539/ijef.v9n5p58

Jones, E., Danbolt, J. \& Hirst, I., 2004, 'Company investment announcements and the market value of the firm', The European Journal of Finance 10(5), 437-452. https://doi.org/10.1080/1351847032000168696

Jung, K., Kim, Y.C. \& Stulz, R., 1996, 'Timing, investment opportunities, managerial discretion, and the security issue decision', Journal of Financial Economics 42(2), 159-186. https://doi.org/10.1016/0304-405X(96)00881-1

Kato, K. \& Schallheim, J.S., 1993, 'Private equity financings in Japan and corporate grouping (keiretsu)', Pacific-Basin Finance Journal 1(3), 287-307. https://doi.org/ 10.1016/0927-538X(93)90028-G

Kim, W. \& Weisbach, M.S., 2008, 'Motivations for public equity offers: An international perspective', Journal of Financial Economics 87(2), 281-307. https://doi.org/ 10.1016/j.jfineco.2006.09.010

Korajczyk, R.A., Lucas, D.J. \& McDonald, R.L., 1992, 'Equity issues with time-varying asymmetric information', Journal of Financial and Quantitative Analysis 27(03), 397-417. https://doi.org/10.2307/2331327

Loughran, T. \& Ritter, J.R., 1995, 'The new issues puzzle', The Journal of Finance 50(1) 23-51. https://doi.org/10.1111/j.1540-6261.1995.tb05166.x

Myers, S.C. \& Majluf, N.S., 1984, 'Corporate financing and investment decisions when firms have information that investors do not have', Journal of Financial Economics 13(2), 187-221. https://doi.org/10.1016/0304-405X(84)90023-0

Pilotte, E., 1992, 'Growth opportunities and the stock price response to new financing', Journal of Business 65, 371-394. https://doi.org/10.1086/296576

Ritter, J.R., 1991, 'The long-run performance of initial public offerings', The Journal of Finance 46(1), 3-27. https://doi.org/10.1111/j.1540-6261.1991.tb03743.x

Ritter, J.R., 2003, 'Investment banking and securities issuance', Handbook of the Economics of Finance 1, 255-306. https://doi.org/10.1016/S1574-0102(03) 01009-4

Smith, C.W., 1986, 'Investment banking and the capital acquisition process', Journal of Financial Economics 15(1), 3-29. https://doi.org/10.1016/0304-405X(86) 90048-6 